\title{
sciendo
}

\section{Emerging trends and drivers for knowledge-intensive economy}

\author{
Adriana GRIGORESCU \\ National School for Political and Administrative Studies, Bucharest, Romania \\ adrianagrigorescu11@gmail.com \\ Ana-Maria ZAMFIR \\ National Scientific Research Institute for Labour and Social Protection, Bucharest, Romania \\ anazamfir@incsmps.ro \\ Cristina MOCANU \\ National Scientific Research Institute for Labour and Social Protection, Bucharest, Romania \\ mocanu@incsmps.ro
}

\begin{abstract}
Innovation and knowledge-intensive economy are considered crucial for addressing challenges and opportunities currently faced by Europe. The present paper aims to provide inputs for building a long-term vision aiming to promote innovation and knowledge economy for fostering smart, sustainable and inclusive growth. We analyze microdata from the 2016 Innobarometer "EU Business Innovation Trends" (Flash Eurobarometer 433), covering 14,112 companies from 30 countries in order to shed light on main drivers and results of business investments in innovation. We focus our analysis on high-tech industries and knowledge-intensive services. Additionally, expected positive impacts of innovation in knowledge-intensive sectors are explored in terms of job creation, digital economy, environment protection, health, transport, food quantity and quality, development of smart cities, etc. Our results are useful for designing an improved support for the emergence and impact of knowledgeintensive economy.
\end{abstract}

Keywords: knowledge-intensive, innovation, business investments, sustainability.

Please cite the article as follows: Grigorescu, A., Zamfir, A.M., Mocanu, C. (2020), "Management \& Marketing. Challenges for the Knowledge Society", Vol. 15, No. 2, pp. 172-185, DOI: 10.2478/mmcks2020-0011.

\section{Introduction}

The evolution of the economy towards a more knowledge intensive one is considered an important and desirable structural change (European Commission, 2011; Vertesy \& Van Roy, 2013). In the last two decades, the EU economy has become more knowledge-intensive, but the gap with the United States is far to be closed. The national and regional strategies and policies define a framework that can be conducive to the stimulation of these structural changes and these policies need to be improved and adapted based on specific features and evolutions at national or sectoral level (World Economic Forum, 2011). Our paper aims to provide evidences in this respect.

Malerba et al. (in Vertesy \& Van Roy, 2013, p.1) have found three categories of indicators reflecting this structural change: enablers, compositional and Schumpeterian. Enablers refer to the context factors in a country that support or hinder innovation in 
companies (i.e., business environment, attitudes towards science and technology or available venture capital). Indicators on compositional structural change measure shifts in the sectoral composition of the economy in terms of research and development (R\&D), skills, output, exports, technologies and foreign direct investment (FDI). Schumpeterian structural change indicators characterise the micro level, referring to the dynamics of innovation and entrepreneurship at the level of companies and markets. The present paper is focused on Schumpeterian level by studying innovation behavior among knowledge intensive companies.

In the vision of the European Commission (2011), the innovation emergence needs to be enhanced and the building of the Innovation Union plays an important role for achieving the Europe 2020 strategy for growth and jobs. Special attention needs to be paid to private research effort which influences innovation and technological output. In order to boost innovation in companies, framework conditions and eco-innovation systems need to become more supportive with companies (European Commission, 2011; Davidescu et al., 2015). In order to support these efforts, we analyze company level data aiming to shed light on main drivers and patterns of business investments in innovation, focusing on knowledge-intensive sectors.

\section{Literature review}

According to the evolutionary economics, there is an important variation between sectors in terms of technological regimes, resulting in variations in industrial dynamics and in patterns of innovative activities (Malerba \& Orsenigo, 1997; Breschi et al., 2000). It is highlighted the existence of co-evolutionary processes in the economy in relation to knowledge, structure of the organisations and institutions (Nelson, 1994; Metcalfe, 2001; Murmann, 2013). For instance, the co-evolution of scientific knowledge and innovation determines the emergence of new industries based on the creation, diffusion and use of knowledge, such is the case of biotechnology (McKelvey, 1996). Building on this theoretical strand, we are interested to explore patterns of co-evolution in terms of innovation within knowledge intensive sectors.

Another relevant theoretic strand is the innovation system approach. Companies are not isolated and they interact with a variety of actors (suppliers and clients, research organisations, authorities, financial organisations, etc.) within their institutional setting (Edquist \& McKelvey, 2000). Innovation systems act at national, regional and sectoral levels (Dima et al., 2016). National innovation systems refers to country level institutions, boundaries and links between actors. In the case of regional innovation systems, the focus is on interactions among companies, clusters and actors and the way they share and exchange knowledge. Sectoral innovation systems highlight variations between sectors in terms of knowledge and institutions that support innovation. Such variations across sectors determine differences in knowledge base of innovative activities (Malerba, 2002; Malerba \& McKelvey, 2018; Doloreux \& Frigon, 2019).

The innovation processes and the patterns of knowledge exchange in knowledge intensive sectors differ from those in other sectors (Tödtling et al., 2006). OECD (2006) research shows that knowledge-intensive service activities are very important for the innovation processes as they act as sources, facilitators and carriers of innovation. Moreover, it is acknowledged that innovation is a collective process based on interactions among participants, including users and clients who are relevant drivers of innovation. Moreover, other internal and external capabilities are very important drivers of innovation, such as an 
effective human resources management, appropriate organisational structures, effective networks, market-based transactions. Wu \& Chen (2019) have showed that technological regimes influences innovativeness of the companies in knowledge-intensive industries. Additionally, research-based knowledge and a highly skilled labour force play a very important role for innovation in knowledge intensive sectors (OECD, 2006; Marzucchi \& Montresor, 2017). Such conclusions have been confirmed by the results of Ciriaci (2017) showing that investments in training and the volume of R\&D staff have a positive impact on firms' innovativeness. Other predictors related with the investment behavior of the companies have been explored. For example, Ghisetti \& Montresor (2019) have analysed the role of investments in design for the propensity of companies to eco-innovate. Montresor \& Vezzani (2016) have shown that intangible investments of companies increases the acquiring of knowledge leading to increased innovativeness.

\section{Methodology}

This paper is based on the analysis of microdata from the 2016 Innobarometer "EU Business Innovation Trends" (Flash Eurobarometer 433), covering 14,112 companies from 30 countries (28 EU countries, as well as Switzerland and the United States of America). Data have been collected in February 2016. The sample includes companies with 1 or more employees in manufacturing (NACE category C), the industry sector (NACE categories D, E, F), and services (NACE categories G, H, I, J, K, L, M, N, R). Interviews have been carried out via telephone with key decision makers of selected companies.

The Innobarometer "EU Business Innovation Trends" has explored a wide range of topics such as: profile of innovative companies, types of innovations, commercialization of innovative goods and services, investments in innovation, role of design and advanced manufacturing technologies in the company, future intentions regarding innovation and expected impacts.

As stated above, we focus our analysis on high-tech industry and knowledgeintensive services (HTEC). According to Eurostat, two main approaches are used to assess technology-intensity: the sectoral approach and the product approach. We use data resulted from the sectoral approach. In the case of manufacturing industries, the classification takes into account the technological intensity (R\&D expenditure/value added) and composes four classes: high-technology, medium high-technology, medium low-technology and lowtechnology industries. Services sectors are aggregated into knowledge-intensive services and less knowledge-intensive services based on the share of tertiary educated persons. So, based on the sectoral approach and classifications provided by Eurostat, we classified the sample of companies in three categories: high-tech industry, knowledge-intensive services and other sectors.

First, we are interested to explore the relation between knowledge intensity and innovation. We study the company-level factors that act as predictors for innovation and if such factors are different for knowledge intensive economy. As the dependent variable is binary (innovation introduced by the company in the last three years), we perform logistic regression for this purpose.

Second, we analyze patterns of investment in innovation among companies by knowledge intensity, as well as the expected outcomes of the investment strategies using the correspondence analysis. Correspondence analysis is a descriptive multivariate method applied to categorical data (Phillips, 1995). It is a technique usually used for exploratory 
approaches (Doey, Kurta, 2011). Correspondence analysis practically evidences how variables are associated by the distance between different points on a biplot (StatSoft, Inc., 2010). The technique uses chi-square in order to measure the distance between the points (Doey, Kurta, 2011). Analyses were run using SPSS 23 on the weighted data, using the weighting variable provided by the dataset (WEIGHT TOTAL).

Through the employed methods, this paper provides new evidences with regard to the link between investment behaviors of the companies and their propensity to innovation, with focus on knowledge-intensive sectors. The novelty of the study is related to the fact that it explores the influence of a wide range of types of investments, including in tangible and non-tangible assets, on innovativeness of the companies, while paying a special attention to the knowledge-intensive sectors. Additionally, the application of the correspondence analysis allows us to improve the existing knowledge on the association between patterns of investments, knowledge intensity and expected positive impacts of innovation by providing very visual outputs. From both the theoretical and practical perspectives, such outputs can be useful for decision makers and managers to better understand or anticipate the impacts associated to various investments behaviors at company level.

\section{Results and discussions \\ Drivers for innovation in companies}

In order to understand the main drivers of innovation among companies and especially knowledge-intensive companies, we constructed two models of logistic regression (Table 1). First model was applied on the total sample of companies, while the second model was applied on the sample of knowledge-intensive companies (from both high-tech industries and knowledge-intensive services). While the significant predictors are quite similar, the intensity of their influence differs between the two samples. At the level of total sample of companies, in comparison with manufacturing enterprises, services, as well as electricity, water and construction companies have lower odds of introducing at least one innovation in the last three years. On the other hand, companies from retail do not display chances of innovation significantly different from the manufacturing companies. In the case of knowledge intensive companies, the sectors to which they belong has no influence on the innovation behavior. The volume of turnover impacts the companies' capacity to innovate for both samples. Higher the turnover, higher the chances of having introduced at least one innovation. For the total sample, companies with the turnover more than 2 million of euros have higher probabilities to innovate as compared with companies with the turnover up to 100,000 euros, while for the knowledge-intensive companies, the statistical relation is significant above the threshold of 500,000 euros. Moreover, the influence of turnover on the innovation potential is higher among knowledge-intensive companies. Also, for the total sample of companies, investments in training, software development, acquisition of machines, equipment, software or licenses, research \& development, organisation or business process improvements, design of products and services and company reputation and branding, including web design increase the propensity of companies towards innovation. Out of these factors, the most important predictors for innovation are the investments in organisation or business process improvements and the investments in design of products and services. All the above mentioned predictors are also significant for the sub-sample of knowledge-intensive companies, with the exception of investment in training and in company reputation and branding, including web design. Also, in the case of 
knowledge-intensive companies, the investments in organisation or business process improvements and investments in the design of products and services represent the strongest drivers for innovation, but their influence on the probability of introducing at least one innovation is significantly higher than for the total sample of companies.

Table 1. Results of logistic regression (method: Enter) - dependent variable: (1=at least one innovation, $0=$ no innovation at all)

\begin{tabular}{|c|c|c|c|c|}
\hline & \multicolumn{2}{|c|}{$\begin{array}{l}\text { Model 1: Total sample of } \\
\text { companies }\end{array}$} & \multicolumn{2}{|c|}{$\begin{array}{c}\text { Model 2: } \\
\text { Knowledge- } \\
\text { intensive companies }\end{array}$} \\
\hline & $\operatorname{Exp}(B)$ & Sig. & $\operatorname{Exp}(B)$ & Sig. \\
\hline \multicolumn{5}{|l|}{$\begin{array}{l}\text { Sector (ref. = Manufacturing for Model } 1 \text { and High- } \\
\text { tech industries for Model 2) }\end{array}$} \\
\hline $\begin{array}{r}\text { Sector (Services for Model } 1 \text { and Knowledge-intensive } \\
\text { services for Model 2) }\end{array}$ & 0.788 & 0.002 & 0.799 & 0.518 \\
\hline Sector (Retail) & 1.041 & 0.618 & - & \\
\hline Sector (Electricity, water, construction) & 0.681 & 0.000 & - & \\
\hline \multicolumn{5}{|l|}{ Total turnover (ref. = Up to 100000 euros) } \\
\hline More than 100000 to 500000 euros & 1.113 & .124 & 1.196 & .201 \\
\hline More than 500000 to 2 million euros & 1.126 & .097 & 1.646 & .002 \\
\hline More than 2 to 10 million euros & 1.212 & .012 & 1.574 & .007 \\
\hline More than 10 to 50 million euros & 1.243 & .016 & 1.842 & .004 \\
\hline More than 50 million euros & 1.592 & .005 & 2.309 & .014 \\
\hline \multicolumn{5}{|l|}{ Investment in training (ref. = no investment) } \\
\hline Some investment & 1.262 & 0.000 & 1.207 & 0.131 \\
\hline \multicolumn{5}{|l|}{$\begin{array}{l}\text { Investment in software development (ref. = no } \\
\text { investment) }\end{array}$} \\
\hline Some investment & 1.252 & 0.000 & 1.262 & 0.038 \\
\hline \multicolumn{5}{|l|}{$\begin{array}{l}\text { Investment in acquisition of machines, equipment, } \\
\text { software or licenses (ref. = no investment) }\end{array}$} \\
\hline Some investment & 1.498 & 0.000 & 1.346 & 0.012 \\
\hline \multicolumn{5}{|l|}{$\begin{array}{l}\text { Investment in research \& development (ref. = no } \\
\text { investment) }\end{array}$} \\
\hline Some investment & 1.49 & 0.000 & 1.502 & 0.001 \\
\hline \multicolumn{5}{|l|}{$\begin{array}{l}\text { Investment in organisation or business process } \\
\text { improvements (ref. = no investment) }\end{array}$} \\
\hline Some investment & 2.654 & 0.000 & 3.137 & 0.000 \\
\hline \multicolumn{5}{|l|}{$\begin{array}{l}\text { Investment in design of products and services (ref. } \\
=\text { no investment) }\end{array}$} \\
\hline Some investment & 2.324 & 0.000 & 2.738 & 0.000 \\
\hline \multicolumn{5}{|l|}{$\begin{array}{l}\text { Investment in company reputation and branding, } \\
\text { including web design (ref. = no investment) }\end{array}$} \\
\hline Some investment & 1.300 & 0.000 & 1.166 & 0.232 \\
\hline Nagelkerke R Square & \multicolumn{2}{|c|}{0.277} & \multicolumn{2}{|c|}{0.327} \\
\hline Overall correct percentage & \multicolumn{2}{|c|}{$77.4 \%$} & \multicolumn{2}{|c|}{$79.5 \%$} \\
\hline
\end{tabular}

Source: Authors' own research on the dataset of Flash Eurobarometer 433 (European Commission, 2016).

\section{Patterns of investments' behavior among companies active in knowledge-intensive economy}

As it was stated above, we based our exploratory analyses on the technique of correspondence analyses. In order to evidence the patterns of investments' behavior among companies we use the information provided by the items measuring the percentage of 
company's turnover invested in innovation activities during 2015, as well as the rhythm of investments planned for the next 12 months. Analyses are run for the entire population of companies and the two items are cross-tabulated with the variable defining the membership to one of the knowledge-intensive sectors (high-tech industries, knowledge-intensive services) or to other sectors.

First of all, we analyze the correlation between the intensity of investments in innovation and the type of economic activity. The biplot provided in Figure 1 includes the correspondence analyses and evidences specific patterns of investment. For instance, the knowledge-intensive services are associated with higher shares of their turnover invested in innovation during 2015, being closer to the categories marking shares of investment between 6 and $10 \%$ or even more than $11 \%$. On the other hand, the rest of the sectors are closer to the categories marking no investments or less than $5 \%$. We also have to point out that companies from high-tech industries do not display a specific pattern of investments in innovation.

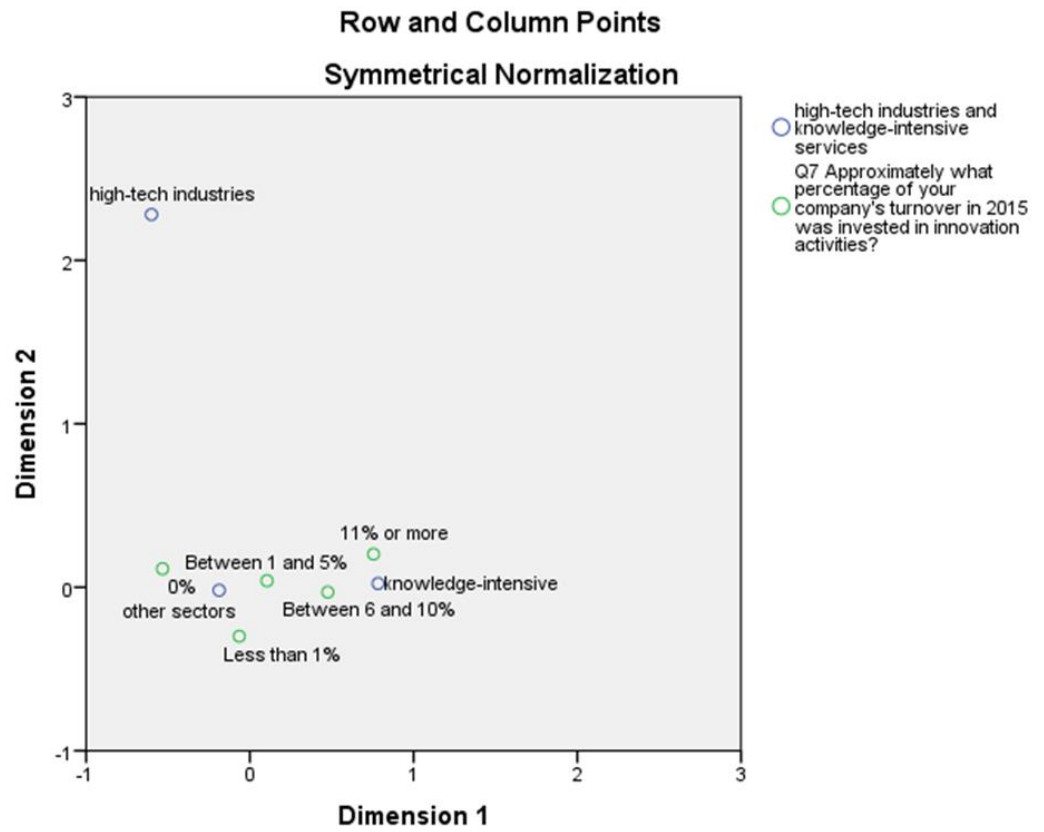

Figure 1. Correspondence analysis between type of sector and share of company's turnover invested in innovation in 2015

Source: Authors' own calculations on the dataset of Flash Eurobarometer 433 (European Commission, 2016). 


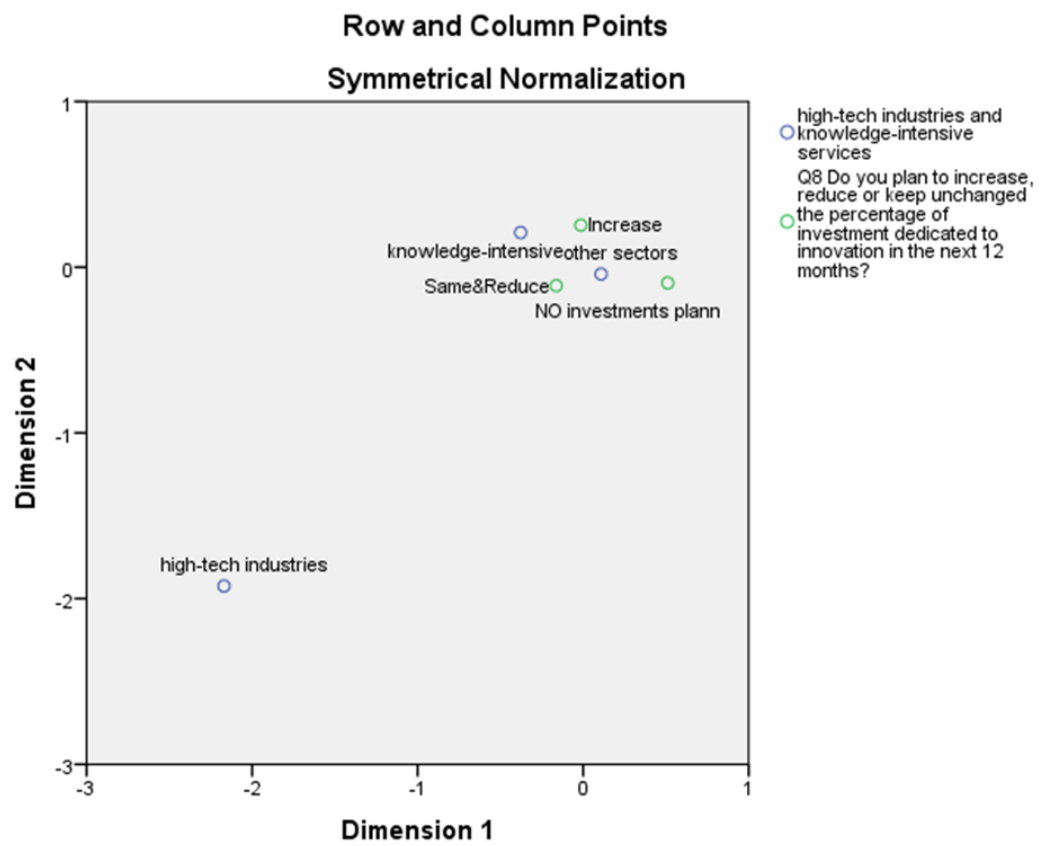

Figure 2. Correspondence analysis between type of sector and plans to invest in innovation for the next 12 months

Source: Authors' own calculations on the dataset of Flash Eurobarometer 433 (European Commission, 2016).

We also analyze the planned investments for the next 12 months. Figure 2 evidences the results of the correspondence analyses, where one can see that knowledge-intensive services are associated with the category marking a planned increase in the share of turnover invested in innovation. In the same time, the rest of the sectors are closer to the categories showing the same or reduced investment in innovation. Once again, companies in high-tech industries do not display a particular pattern of the planned investments in innovation.

Correspondence analysis carried out support the conclusion that knowledgeintensive services are more likely to display a more consistent strategy of investment in innovation, with subsequent higher shares of turnover invested in this direction.

\section{Expected positive impacts of innovation in knowledge-intensive economy}

Expected positive impacts of innovation and especially of innovation in knowledge-intensive sectors are explored in terms of job creation, digital economy, environment protection, health, transport, food quantity and quality, development of smart cities, etc. $62.3 \%$ of companies estimate that their investments plans will lead to some positive outcomes for society.

High-tech industries estimate that their most relevant outcomes will be in the areas of environmental protection $27.3 \%$ of companies planning investments for the following 5 years), transport and infrastructure (18.2\%), health and medical care $(14.3 \%)$, as well as space applications (4.1\%).

On the other hand knowledge-intensive services estimate that the positive outcomes of their investment plans will influence mainly IT and digital economy (19.9\%) and lifelong learning and skills improvement (17.3\%). 
Contribution to job generation and availability and quality of foods remain as having their main source in innovation of the rest of the economic sectors. As compared to them, knowledge-intensive sectors have a lower impact in relation to these societal needs.

Also the analysis evidences that resource efficiency or construction solutions for future smart cities are not among the most significant areas of impact for innovation of knowledge-intensive sectors. So, more attention on the need to promote new solutions for circular economy coming from the knowledge-intensive services could be a strand of action for the years to come.

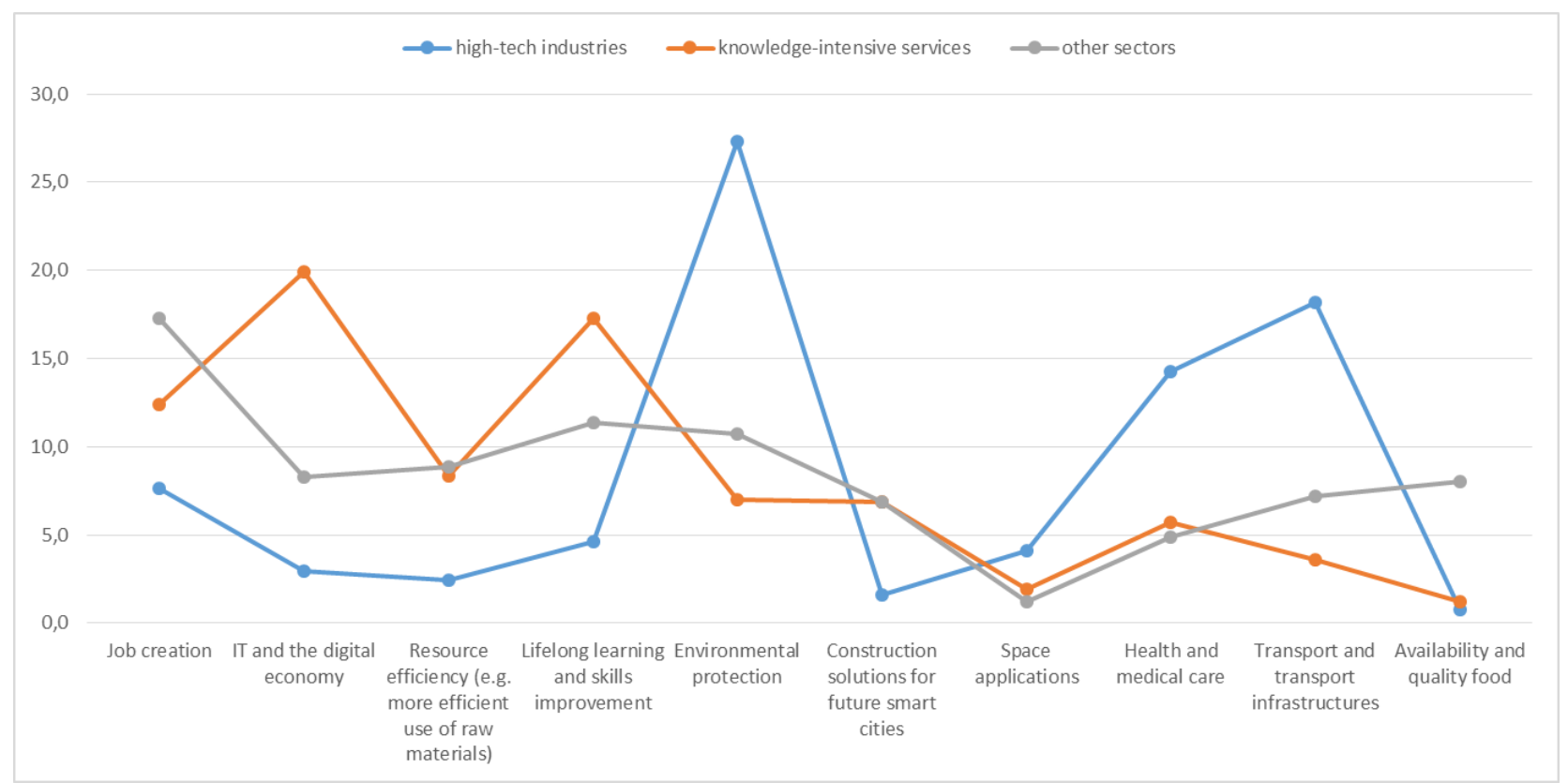

Figure 3. Expected positive impacts of innovation by type of sector

Source: Authors' own calculations on the dataset of Flash Eurobarometer 433 (European Commission, 2016).

We continue our analyses by summing up the number of areas where positive outcomes are mentioned by the surveyed companies. $40.8 \%$ of the companies estimate that their plans for investments will have a significand impact in none of the mentioned areas. Approximately one third (31.5\%) mentions only one area of impact, while $27.7 \%$ point to two areas of positive impacts. 


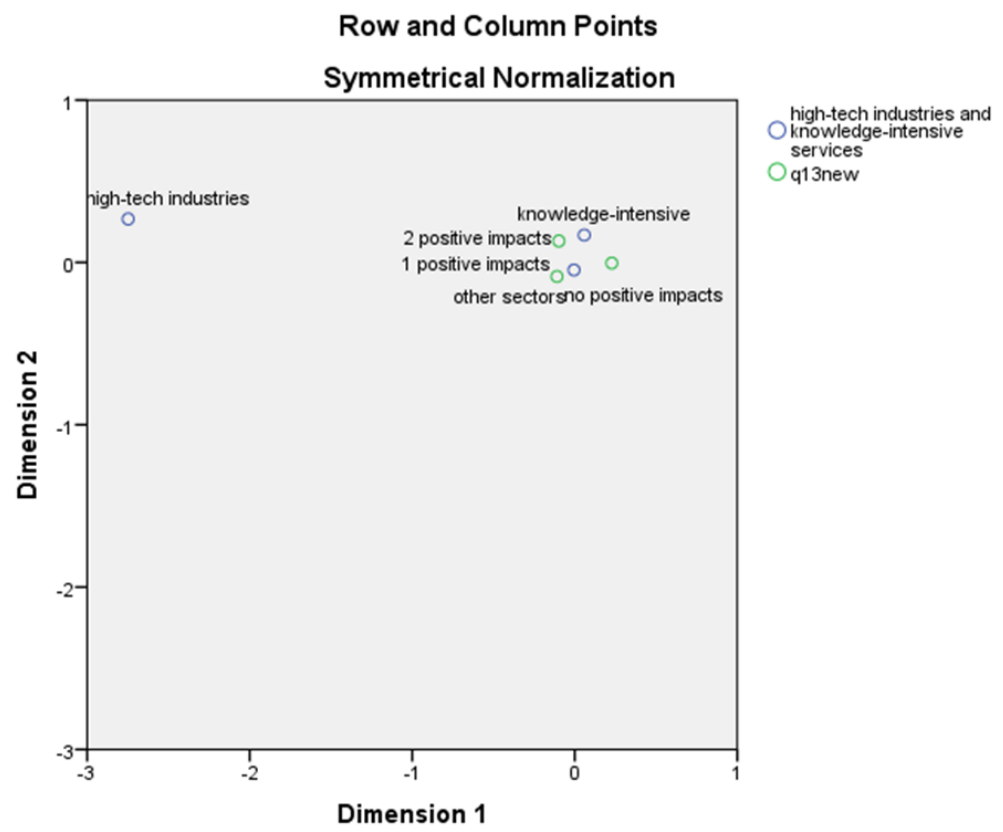

Figure 4. Correspondence analysis between type of sector and number of areas where positive impacts are expected

Source: Authors' own calculations on the dataset of Flash Eurobarometer 433 (European Commission, 2016).

We carried out a correspondence analyses in between the number of expected areas for positive outcomes and type of economic sector, the findings being presented in Figure 4 . The biplot evidences a strong correlation in between companies declaring they are active in knowledge-intensive services and those declaring they estimate two areas of positive outcomes. On the other hand, we also can visualize a strong correlation in between companies declaring they are active in other economic sectors and those declaring they anticipate only one area of positive outcomes. So, companies active in knowledge-intensive services are more probable to determine more diverse impacts addressing different societal needs.

\section{Links between investment patterns and expected positive impact in knowledge-intensive economy}

In order to evidence the links between investment's patterns and expected outcomes on the societal needs we further focused our analyses only on the companies active in knowledgeintensive economy.

We analyse for the knowledge-intensive companies the correlation between the intensity of investments in innovation and the number of areas where positive impacts are expected. The biplot provided in Figure 5 evidences some strong correlations between patterns of investment and areas for positive outcomes. First of all, as expected, we notice the strong correlation between those companies declaring they had no investments in innovation for 2015 and those declaring no areas for impact for the years to come. The companies investing up to 5\% on their turnover in innovation in 2015 are closer to those declaring only one area of impact for the years to come, while those declaring more than $6 \%$ of their turnover in innovation are closer to the companies declaring their innovation activities will impact two areas of societal needs. 


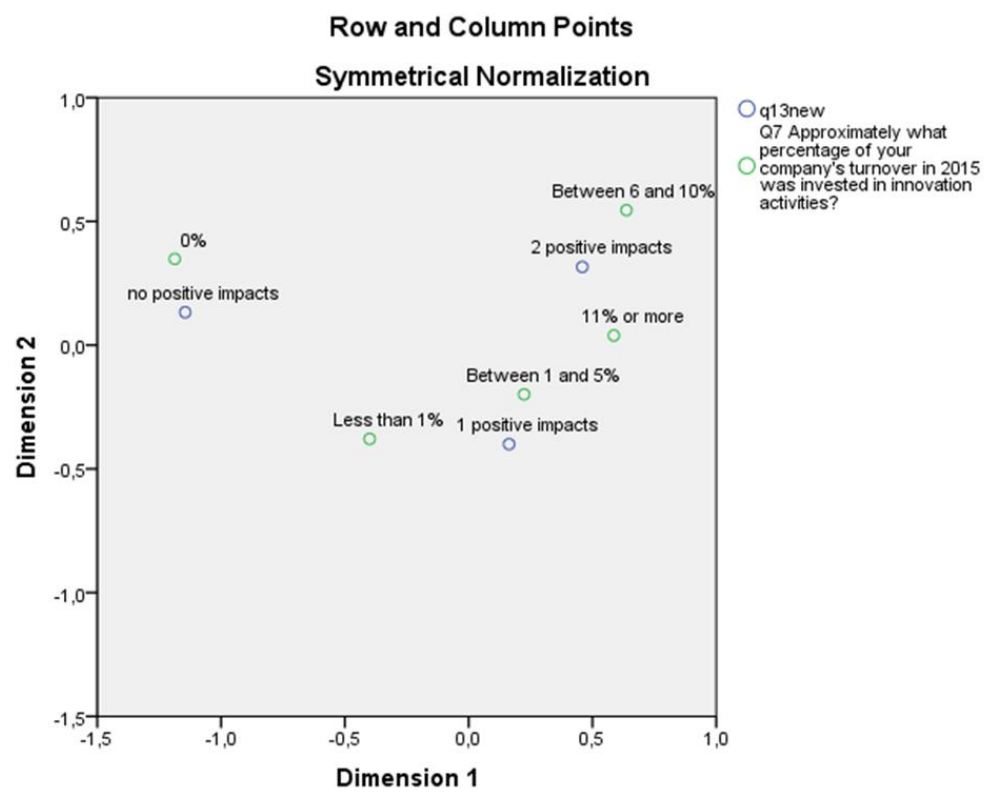

Figure 5. Correspondence analysis between the number of areas where positive impacts are expected and share of company's turnover invested in innovation in 2015

Source: Authors' own calculations on the dataset of Flash Eurobarometer 433 (European Commission, 2016).

Same analyses, but run for the investments' strategies planned for the next 12 months emphasize the correlation in between companies declaring their activities will impact two areas of societal needs and the companies aiming to maintain or increase the percentage of their turnover invested in innovation (see Figure 6).

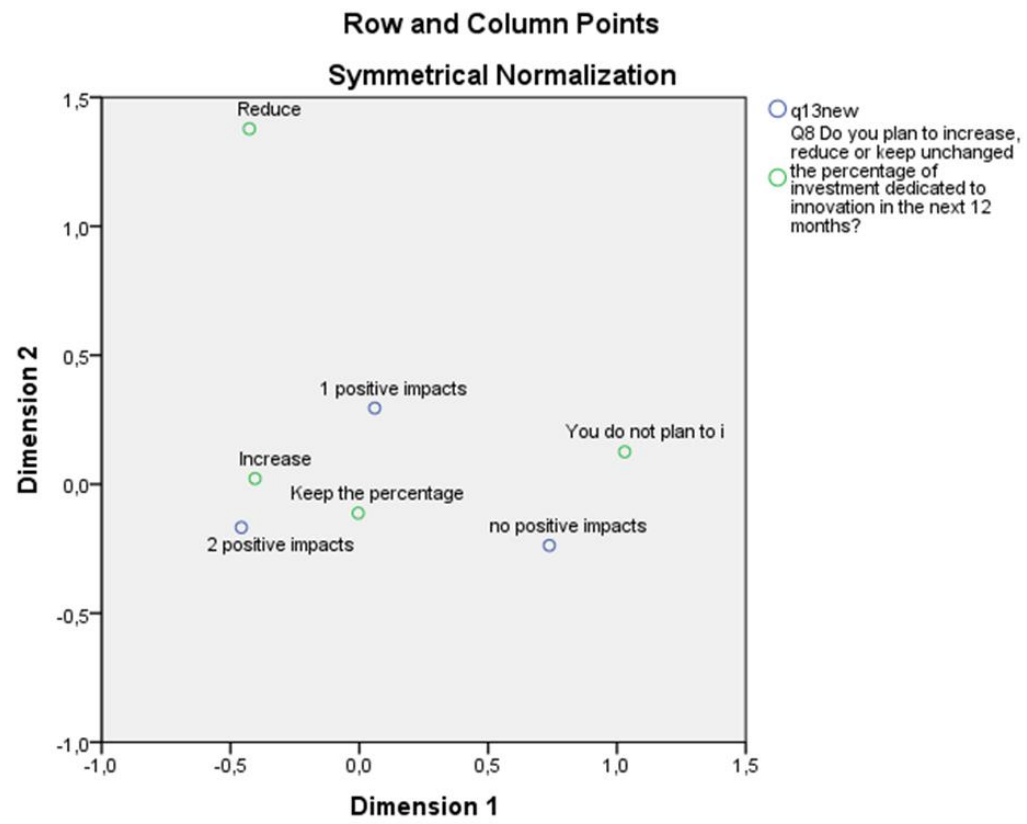

Figure 6. Correspondence analysis between the number of areas where positive impacts are expected and plans to invest in innovation for the next 12 months

Source: Authors' own calculations on the dataset of Flash Eurobarometer 433 (European Commission, 2016). 
For the last correspondence analyses of our paper, we created a new variable by crosstabulation of past and future plans for investment in innovation. The variable created has four categories: (1) companies that had no investments in innovation in 2015 and no plans to invest in the next 12 months (NO past and future), (2) companies that had no investments in innovation in 2015, but some plans to invest in the next 12 months (YES in future), (3) companies that had some investments in innovation in 2015, but no plans for the next 12 months (YES in past) and (4) companies that had some investments in innovation in 2015 and plans to invest in the next 12 months (YES past and future). In this way, we can distinguish in between companies having a consistent strategy for innovation from those having less or none strategies for investing in innovation.

The biplot presented in Figure 7 evidences the strong correlation in between companies active in knowledge-intensive sectors but with no investments in innovation and those declaring no areas for positive impacts for the next 5 years. On the other hand, it is more probable for companies that had and continues to invest in innovation to influence two areas of positive outcomes for the next 5 years.

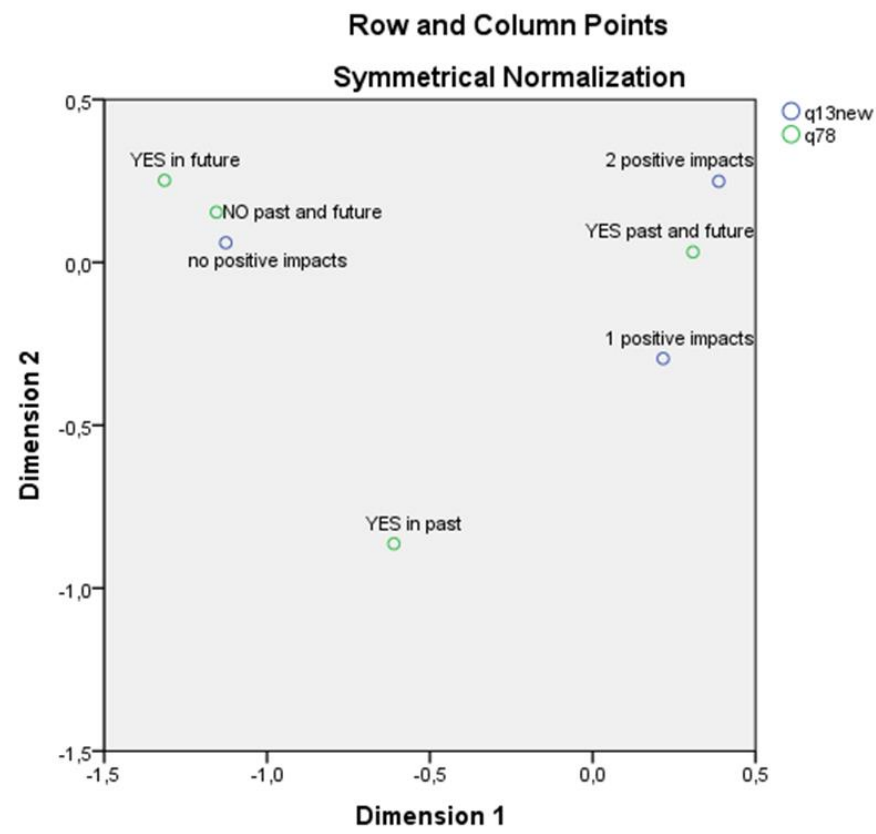

Figure 7. Correspondence analysis between the number of areas where positive impacts are expected and strategies of investment in innovation

Source: Authors' own calculations on the dataset of Flash Eurobarometer 433 (European Commission, 2016).

So, the investment strategies of companies activating in knowledge-intensive sectors are essential to have a significant impact on the current issues for sustainable development. Developing adequate support programs for these companies and raising awareness on their potential contribution to society could lead to some peaks both for their activity, as well as for their contribution to providing solutions for different societal needs. 


\section{Conclusions}

This paper has analysed data provided by the Flash Eurobarometer 433 (European Commission, 2016), focusing on the behavior of knowledge intensive companies in relation with innovation. First, we explored the main drivers of innovation and we find out that investment in organisation or business process improvements and investments in design of products and services are the strongest predictors for innovation among the entire population of companies. Moreover, such investments influence even stronger the propensity to innovation among knowledge-intensive services.

Second, we find that knowledge intensity is strongly correlated with higher past and future investments in innovation in the case of services, while companies from high tech industries do not display a specific pattern in this matter. In conclusion, our results are consistent with theories of evolutionary economics, finding patterns of co-evolution in terms of innovation among companies from knowledge intensive services, which can support the emergence of knowledge based economic niches. On the other hand, in the case of high-tech industries, we find no evidence of co-evolution of innovation investments. This result supports the relevance and influence of sectoral innovation systems and the need of targeting support measures for enhancing innovation in high-tech industries.

Third, innovation of companies from high tech industries has important positive outcomes at the level of environmental protection, transport and infrastructure, as well as health and medical care. On the other hand, innovation of companies from knowledge intensive services impacts positively IT and digital economy, as well as lifelong learning and skills improvement. Considering that these areas are less impacted by innovation from the other sectors, we conclude that policies and programs targeting to support innovation among knowledge intensive companies are very important for social and economic progress, while addressing sustainability goals. Such a long term vision will foster a smart, sustainable and inclusive growth for Europe.

Main limitation of the present study is related to the fact that the data have been collected in 2016 and the information regarding the level of turnover and investments are registered for the year 2015. Therefore, our results are suggestive for the behavior of companies regarding innovation in that particular period, while their future plans of investments and expected impacts could explain subsequent decisions of the companies in this respect in the last years. Our future plans for research include the application of a multilevel approach of analysis through the introduction of country-level variables for exploring the influence of the national context.

\section{Acknowledgment:}

This paper is part of the Project School of Knowledge Production and Transfer for Global Economy and Governance, funded by Iceland, Liechtenstein and Norway through the EEA Grants, Financial Mechanism 2014-2021 though contract number 18-COP-0032.

\section{References}

Breschi, S., Malerba, F., \& Orsenigo, L. (2000). Technological regimes and Schumpeterian patterns of innovation. The Economic Journal, 110(463), 388-410. https://doi.org/10.1111/1468-0297.00530. 
Ciriaci, D. (2017). Intangible Resources: The Relevance of Training for European Firms' Innovative Performance. Economia Politica 34 (1): 31-54. doi:10.1007/s40888-0160049-8.

Davidescu, A.A., Paul, A.M.V., Gogonea, R.M., \& Zaharia, M. (2015). Evaluating Romanian EcoInnovation Performances in European Context. Sustainability, 7, 12723-12757.

Dima, A.M., Hadad, S., Cantaragiu, R (2016). A conceptual analysis of business-university knoledge transfers in the energy field, Proceedings of the $10^{\text {th }}$ International Conference on Business Excellence. Energy, climate change and sustainability (Eds. Tantau, A, Dima, M.A, Hadad, S.), Editura Business Excellence, ISSN 2502-0226, ISBN 978-606-92299-1-0, pp. 199-205, 6 pg, http://www.bizexcellence.ro/wpcontent/uploads/2016/09/ICBE-10th-edition-e-volume.pdf\#page=202;

Doey, L., \& Kurta, J. (2011). Correspondence Analysis applied to psychological research.

Tutorials in Quantitative Methods for Psychology, 7(1), 5-14. Retrieved from http://www.tqmp.org/RegularArticles/vol07-1/p005/p005.pdf

Doloreux, D., \& Frigon, A. (2019). Innovation in Knowledge Intensive Business Services (KIBS). Can J Adm Sci, https://doi.org/10.1002/cjas.1525.

Edquist, C., \& McKelvey, M. (2000). Systems of innovation: growth. In Competitiveness and employment. Cheltenham: Edward Elgar Publishers.

European Commission (2011). Innovation Union Competitiveness report 2011 edition. http://ec.europa.eu/research/innovation-union/pdf/competitivenessreport/2011/iuc2011-full-report.pdf.

European Commission. (2016). Flash Eurobarometer 433 (Innobarometer 2016 - EU Business Innovation Trends. TNS opinion, Brussels. GESIS Data Archive, Cologne. ZA6771 Data file Version 1.0.0, doi:10.4232/1.12635

Eurostat indicators on High-tech industry and Knowledge - intensive services, Annex 3 High-tech aggregation by NACE Rev.2 https://ec.europa.eu/eurostat/cache/metadata/Annexes/htec esms an3.pdf

Ghisetti, C., \& Montresor S. (2019). Design and eco-innovation: micro-evidence from the Eurobarometer survey. Industry and Innovation, 26:10, 1208-

1241, DOI:10.1080/13662716.2018.1549475

Malerba, F. (2002). Sectoral systems of innovation and production. Research Policy, 31(2), 247-264. https://doi.org/10.1016/S0048-7333(01)00139-1

Malerba, F., \& Mckelvey, M. (2018). Knowledge-intensive innovative entrepreneurship integrating Schumpeter, evolutionary economics, and innovation systems. Small Business Economics. 1-20.10.1007/s11187-018-0060-2.

Malerba, F., \& Orsenigo, L. (1997). Technological regimes and sectoral patterns of innovative actvities. Industrial and Corporate Change, 6(1), 83-118.

Marzucchi, A., \& Montresor, S. (2017). Forms of Knowledge and Eco-Innovation Modes: Evidence from Spanish Manufacturing Firms. Ecological Economics 131: 208-221. doi:10.1016/j.ecolecon.2016.08.032.

Montresor, S., \& Vezzani, A. (2016). Intangible Investments and Innovation Propensity. Evidence from the Innobarometer 2013. Industry and Innovation 23 (4): 331-352.

McKelvey, M. (1996). Evolutionary innovations: the business of biotechnology. Oxford: Oxford University Press.

Metcalfe, J. S. (2001). Institutions and progress. Industrial and Corporate Change, 10(3), 561586. https://doi.org/10.1093/icc/10.3.561. 
Murmann, J. (2013). The coevolution of industries and important features of their environments. Organization Science, 24(1), 58-78.

Nelson, R. R. (1994). The coevolution of technology and institutions. Industrial and Corporate Change, 3(1), 47-63. https://doi.org/10.1093/icc/3.1.47.

OECD (2006). Innovation and Knowledge-Intensive Service Activities. ISBN 92-64-02273-2 https://www.oecd.org/innovation/inno/innovationandknowledgeintensiveserviceactivities.htm

Phillips, D. (1995). Correspondence analysis. Social Research Update, Issue 7. Retrieved from http://sru.soc.surrey.ac.uk/SRU7.html.

StatSoft, Inc. (2013). How To Analyze Simple Two-Way and Multi-Way Table, Correspondence Analysis. Electronic Statistics Textbook. Tulsa, OK: StatSoft. Retrieved from http://www.statsoft.com/Textbook/Correspondence-Analysis

Tödtling F., Lehner P. \& Trippl M. (2006). Innovation in knowledge intensive industries: The nature and geography of knowledge links. European Planning Studies, 14:8, 10351058, DOI: $10.1080 / 09654310600852365$.

Vertesy, D., \& Van Roy, V. (2013). Update on the Composite Indicators of Structural Change towards a More Knowledge-Intensive Economy. Reference Report by the Joint Research Centre of the European Commission, doi: 10.2788/51665.

World Economic Forum (2011). The Global Competitiveness Report 2011-2012. http://www3.weforum.org/docs/WEF GCR Report 2011-12.pdf.

Wu, C.-h. \& Chen, M.-N. (2019). Technological regimes in knowledge-intensive industries: The effects on firm innovation behaviour. Proceedings, 1, https://doi.org/10.5465/AMBPP.2019.14116abstract 